\title{
Kateter Epidural Terputus Saat Dipasang
}

\section{Epidural Catheter Breakage during Insertion}

\author{
Muhammad Faizal Hadiyanto ${ }^{\Delta^{*}}$, Doso Sutiyono ${ }^{*}$ \\ *Departemen Anestesiologi dan Terapi Intensif, Fakultas Kedokteran, Universitas Diponegoro/ RSUP Dr. Kariadi, Semarang \\ ${ }^{\square}$ Corespondence/ Korespondensi :faizal.anest@gmail.com
}

\section{ABSTRACT}

Background : Epidural anesthesia is a type of regional anesthesia and is a form of neuroaxial block technique, where its common use than spinal anesthesia. The epidural technique is very widely used in operative anesthesia, analgesia for obstetric cases, postoperative analgesia and for chronic pain. Morbidity and even postoperative mortality can be reduced when neuroaxial blockade is used, either as a single agent or as a combination with general anesthesia.

Cases : A woman 45 years with Gastric Adenocarcinoma who underwent Partial Gastrectomy. Preoperative assessment showed that the patient was in optimal condition. Procedure of anesthesia with Epidural technique, inserted at the site of intervertebrae lumbal space 3- 4 with catheter epidural, but the epidural space was encountered and it sheared off $1 \mathrm{~cm}$ while the catheter was being removed. Anesthesia technique was converted to general anesthesia intubation.

Discusion :The damage of catheter is a complication that can be recognized in epidural anesthesia, and is is often associated with trauma to epidural needle puncture or excessive force during catheter withdrawal. CT scan is more sensitive than MRI in detecting catheter fragments in the epidural space and more sensitive to plain radiographs, especially for small fragments. Postoperative management, epidural catheter pieces that are considered foreign objects are generally considered as inactive and should not produce a body reaction.

Conclusion : Although it is said that a piece of epidural catheter that is considered a foreign object generally does not produce a body reaction. In most cases, the standard for handling the disruption of the epidural catheter segment, is to leave it under surveillance until symptomatic symptoms appear. However, there are situations where appointment operations must be carried out

Keyword: epidural catheter; epidural space; gastric adenocarcinoma; neurological complication; partial gastrectomy. 


\section{ABSTRAK}

Latar belakang : Anestesia epidural adalah satu bentuk dari anestesia regional dan merupakan salah satu bentuk teknik blok neuroaksial, dimana penggunaannya lebih luas daripada anesthesia spinal. Teknik epidural sangat luas penggunaanya pada anestesia operatif, analgesia untuk kasus obstetri, analgesia post operatif dan untuk nyeri kronis. Morbiditas dan bahkan mortalitas pascaoperasi dapat dikurangi ketika blokade neuraksial digunakan, baik sebagai agen tunggal maupun sebagai kombinasi dengan anestesi umum.

Kasus : Seorang wanita usia 45th, ASA II dengan Adenokarsinoma Lambung yang akan menjalani operasi Gastrektomi Parsial. Penilaian preoperasi pasien sudah dalam kondisi yang optimal. Direncanakan akan dilakukan anestesi dengan teknik Epidural, insersi pada ruang intervertebra lumbal 3-4 dengan pemasangan kateter epidural tetapi gagal dipasang dan terputus $1 \mathrm{~cm}$ saat pencabutan. Kemudian teknik anestesi dikonversi menjadi anestesi umum.

Pembahasan : Kerusakan kateter adalah komplikasi yang dapat dikenali pada anestesi epidural, sering dikaitkan dengan trauma pada penusukan jarum epidural atau kekuatan yang berlebihan saat penarikan kateter. Pemeriksaan CT scan lebih sensitif daripada MRI dalam mendeteksi fragmen kateter dalam ruang epidural dan lebih sensitif dengan radiografi polos, terutama untuk fragmen kecil. Pengelolaan post operasi, potongan kateter epidural yang dianggap benda asing umumnya dianggap sebagai tidak aktif dan seharusnya tidak menghasilkan reaksi tubuh.

Kesimpulan : Meskipun dikatakan potongan kateter epidural yang dianggap benda asing umumnya tidak menghasilkan reaksi tubuh. Pada kebanyakan kasus, standard penanganan terputusnya segmen kateter epidural, adalah dengan membiarkan dengan pengawasan sampai muncul gejala simptomatik. Namun, ada situasi di mana operasi pengangkatan harus dilakukan.

Kata Kunci: adenokarsinoma lambung; epidural kateter; gastrektomi parsial; komplikasi neurologis; ruang epidural.

\section{PENDAHULUAN}

Anestesia epidural adalah satu bentuk dari anestesia regional dan merupakan salah satu bentuk teknik blok neuroaksial, dimana penggunaannya lebih luas daripada anesthesia spinal. Epidural blok dapat dilakukan melalui pendekatan lumbal, torak, servical atau sacral (yang lazim disebut blok caudal). Teknik epidural sangat luas penggunaanya pada anestesia operatif, analgesia untuk kasus obstetri, analgesia post operatif dan untuk nyeri kronis. Dampak penurunan rasa nyeri dan simpatektomi yang terjadi akan mengurangi stress paska operasi sebagai proteksi terhadap jantung dan pernafasan dengan memudahkan pasien untuk bernafas dalam, batuk yang adekuat, ekstubasi dini dan mobilisasi awal serta menjaga fungsi pencernaan sehingga mempengaruhi penyembuhan paska 
operasi yang lebih baik. ${ }^{1,2,3}$

Morbiditas dan bahkan mortalitas pascaoperasi dapat dikurangi ketika blokade neuraksial digunakan, baik sebagai agen tunggal maupun sebagai kombinasi dengan anestesi umum. Blok neuraksial juga dapat mengembalikan fungsi gastrointestinal lebih cepat setelah operasi. $^{4}$

\section{KASUS}

Seorang wanita berusia 45 tahun, berat badan $50 \mathrm{~kg}$ didiagnosa adenokarsinoma gaster dilakukan gastrektomi parsial dengan anestesi combine general anestesi dan epidural . Dari anamnesa perioperat tidak didapatkan riwayat alergi obat atau makanan. Tidak didapatkan riwayat sakit seperti asma, diabetes mellitus, ataupun konsumsi antikoagulan. Diketahui pasien selama ini memiliki hipertensi grade 1 dan mendapatkan amlodipin $10 \mathrm{mg}$ tiap malam.

Pemeriksaan fisik secara umum tidak didapatkan kelainan. Tidak didapatkan kelainan tulang ekstremitas maupun vertebra, evaluasi intervertreba space lumbal 3-4 mudah diidentifikasi. Data tambahan rontgen thorak PA, EKG, laboratorium darah lengkap, faal hemostasis, elektrolit, fungsi hati, fungsi ginjal, dan gula darah sewaktu menunjukkan data normal. Dari data tersebut pasien diklasifikasikan status fisik ASA 2 dengan hipertensi. Pasien selanjutnya mendapatkan penjelasan dan menandatangani persetujuan mengenai prosedur anestesi dan bedah yang akan dikerjakan.

Persiapan pembiusan umum dan obat emergensi dipersiapkan sebelum prosedur anestesi dimulai. Pasien mendapatkan injeksi midazolam $2 \mathrm{mg}$ sebelum prosedur anestesi di ruang premedikasi. Pasien diposisikan duduk dan diidentifikasi celah intervertebra lumbal 3-4. Dilakukan tindakan asepsis dan antisepsis, kemudian jarum epidural disuntikkan dengan cara paramedian teknik loss of resistance (LOR) menggunakan cairan NS $0.9 \%$ didapatkan jarak LOR sedalam $5 \mathrm{~cm}$. Kateter epidural baru dimasukkan sepanjang $7 \mathrm{~cm}$ dari tepi kulit dan tertahan. Jarum epidural disuntikkan lagi dengan cara yang sama didapatkan jarak LOR sedalam $5 \mathrm{~cm}$, kateter epidural dimasukkan sepanjang $6 \mathrm{~cm}$ dari tepi kulit dan tertahan lagi. Setelah menarik kateter dan mencabut jarum, tampak kateter epidural terpotong dan tertinggal $1 \mathrm{~cm}$. Bekas luka ditutup dan dilanjutkan dengan general anestesi. Setelah anestesi dinyatakan berjalan, maka operasi dimulai. Operasi berjalan lancar selama 240 menit. Parameter hemodinamik dan respirasi selama prosedur operasi relatif stabil dan tidak membutuhkan obat vasopresor maupun inotropik dan analgesia lain selama prosedur operasi.

Paska operasi diberikan analgesik tramadol 50mg per 8 jam, parasetamol $1000 \mathrm{mg}$ per 8 jam dan ranitidin 50mg per 12 jam. Observasi terhadap keluhan nyeri paska operasi selama 2 hari tidak terdapat gangguan respirasi maupun hemodinamik. Pasien juga tidak mengeluhkan mual muntah dan tidak memerlukan tambahan analgesik lain.

Setelah 7 hari perawatan di ruang biasa, pasien diperbolehkan pulang dengan diberi penjelasan dan pengertian 
mengenai tertinggalnya kateter epidural, serta diminta untuk segera kembali apabila merasakan keluhan di area suntikan disertai demam, ataupun kelainan neurologis. Apabila merasakan nyeri punggung, gangguan sfingter, kelemahan atau mati rasa, disarankan untuk segera kontrol ke rumah sakit.

\section{PEMBAHASAN}

Kerusakan kateter adalah komplikasi yang dapat dikenali pada anestesi epidural, sering dikaitkan dengan trauma pada penusukan jarum epidural atau kekuatan yang berlebihan saat penarikan kateter. Lokasi ujung kateter yang tertinggal biasanya terlihat secara radiologis, tetapi tidak selalu dapat terlihat. Pemeriksaan CT scan lebih sensitif daripada MRI dalam mendeteksi fragmen kateter dalam ruang epidural dan lebih sensitif dengan radiografi polos, terutama untuk fragmen yang kecil. 5,6,7

Pengelolaan post operasi, potongan kateter epidural yang dianggap benda asing umumnya dianggap sebagai tidak aktif dan seharusnya tidak menghasilkan reaksi tubuh. Eksperimen dengan kucing telah ditunjukkan bahwa kateter yang rusak menjadi tertutup oleh jaringan fibrosa setelah sekitar 3 minggu tetap tidak berbahaya di dalam ruang epidural. Benda asing di ruang epidural cenderung tidak bermigrasi (meskipun ini bukan tidak mungkin). Namun, Staats dkk melaporkan pembentukan massa epidural reaktif $(1,5 \mathrm{~cm})$ di sekitar fragmen kateter mengakibatkan stenosis tulang belakang lumbal, pasien tidak bergejala sampai 18 bulan dari insiden. ${ }^{8,9,10}$

$$
\begin{aligned}
& \text { Berbagai komplikasi } \begin{array}{r}
\text { termasuk } \\
\text { abses, hematoma tulang belakang, }
\end{array} \\
& \hline
\end{aligned}
$$

radikulopati, terputus, migrasi, kinking, dan knotting dapat terjadi ketika kateter dimasukkan ke dalam ruang epidural. ${ }^{8}$ Pada kebanyakan kasus, standard penanganan terputusnya segmen kateter epidural, adalah dengan membiarkan dengan pengawasan sampai muncul gejala simptomatik karena operasi pengangkatan bisa justru merugikan dari pada menguntungkan. Namun, ada situasi di mana operasi pengangkatan harus dilakukan apabila (1) terjadi infeksi atau muncul gejala, pemeriksaan fisik dilakukan untuk membantu menentukan spinal level yang terlibat ; (2) Jika ujung proksimal dari segmen terletak di atau tepat di bawah kulit, dapat diambil secara sederhana dengan local anestesi. ${ }^{11,12,13}$

Pengangkatan secara operasi adalah wajib disituasi seperti ini karena bakteri dapat dengan mudah menginfeksi sisa kateter tersebut. $^{14,15,16}$

Penyebab terputusnya kateter epidural antara lain (1) terlalu kuat saat mencabut kateter yang terjebak antara prosesus spinosus vertebral atau di ligamentum flavum atau kateter yang terikat, tertekuk atau melengkung di ruang epidural sehingga meregang atau sobek; (2) me. manipulasi kateter saat menarik kateter melalui jarum Tuohy ; (3) kualitas kateter rendah karena proses pabrikan yang tidak sempurna. ${ }^{17,18,19,20}$

Cara mencegah terputusnya kateter epidural (1) tenaga yang digunakan untuk mengeluarkan kateter seharusnya tidak terlalu kuat, jika resistensi ditemukan, manuver sederhana boleh dilakukan untuk membantu menarik kateter tanpa peregangan atau robek; (2) jarum harus diperiksa ujungnya dan kateter juga diperiksa apakah ada kecacatan dari 
pabrikan sebelum dilakukan insersi; (3) sebaiknya tidak boleh lebih dari $4-5 \mathrm{~cm}$ kateter masuk ke dalam ruang epidural untuk mengurangi risiko terlipat atau terjepit; (4) kateter tidak boleh ditarik melalui jarum logam; (5) pilih kateter dengan kekuatan putus tinggi (kekuatan tarik), dengan diameter yang cukup (16/18G), diproduksi dari produsen yang tepercaya dan dapat diandalkan. ${ }^{21,22,23,24}$

Setiap kejadian terpotongnya fragmen kateter epidural harus didokumentasikan dan dikomunikasikan kepada pasien dan dokter bedah karena perkembangan gejala yang terkait dengan kateter mungkin terjadi dalam hitungan bulan atau tahun. Pasien harus kontrol secara berkala untuk memastikan bahwa ada tidaknya keluhan, infeksi atau radikulopati. Jika gejala berkembang, perlu dilakukan pencitraan tulang belakang untuk mengetahui tingkat keterlibatan potongan kateter epidural dan untuk pertimbangan dilakukannya operasi.

\section{KESIMPULAN}

Anestesi regional khususnya anestesi epidural, sering memiliki komplikasi antara lain adalah kerusakan kateter hal ini sering dikaitkan dengan trauma saat penusukan jarum epidural atau kekuatan yang berlebihan. Meskipun dikatakan potongan kateter epidural yang dianggap benda asing umumnya tidak menghasilkan reaksi tubuh. Pada kebanyakan kasus, standard penanganan terputusnya segmen kateter epidural, adalah dengan membiarkan dengan pengawasan sampai muncul gejala simptomatik. $^{25}$ Namun, ada situasi di mana operasi pengangkatan harus dilakukan. Cara mencegah terputusnya kateter epidural (1) tenaga yang digunakan untuk mengeluarkan kateter seharusnya tidak terlalu kuat, jika resistensi ditemukan, manuver sederhana boleh dilakukan untuk membantu menarik kateter tanpa peregangan atau robek; (2) jarum harus diperiksa ujungnya dan kateter juga diperiksa apakah ada kecacatan dari pabrikan sebelum dilakukan insersi; (3) sebaiknya tidak boleh lebih dari $4-5 \mathrm{~cm}$ kateter masuk ke dalam ruang epidural untuk mengurangi risiko terlipat atau terjepit; (4) kateter tidak boleh ditarik melalui jarum logam; (5) pilih kateter dengan kekuatan putus tinggi (kekuatan tarik), dengan diameter yang cukup (16/18G), diproduksi dari produsen yang tepercaya dan dapat diandalkan. ${ }^{23}$

\section{DAFTAR PUSTAKA}

1. Morgan GE, Mikhail MS. Clinical Anesthesiology, 5th Edition. Philadelphia. Lange Medical Books/ McGraw-Hill Education; 2013, p 1019 - 21.

2. Brown L, David. MD. Atlas of Regional Anesthesia. 4th edition. United state: Elsevier; 2010, 250 3

3. Mitra R, Fleischmann K. Management of the sheared epidural catheter : is surgical extraction really necessary? Journal of Clinical Anesthesia. 2007; 19:310-4.

4. Pant D, Jain P, Kanthed P, Sood J. Epidural catheter breakage: a dilemma. Indian J Anaesth. 2007;51:434 
5. Staats PS,Stinson MS,Lee

R.Lumbar stenosis complicating retained epidural catheter tip. Anesthesiology. 1995;83:1115-18

6. DeArmendi A,Ryan J,Chang H, et al. Retained caudal catheter in a paediatric patient. Paed Anaes. 1992; 2:325-27.

7. Jongleux EF,Miller R,Freeman A. An entrapped epidural catheter in a postpartum patient.Reg Anesth Pain Med. 1998;23:615-17.

8. Collier C. Epidural catheter break- age: a possible mechanism. Int J Obstet Anesth. 2000;9:8793.http://dx.doi.org/10.1054/ ijoa.1999.0354. [PubMed]

9. Gülcü N. The diagnosis and treat- ment in epidural catheter break- ages. Uludağ University Medical Journal. 2007;33:29-32.

10. Lee YH, Hwang HY, Sim WS, Yang M, Lee CJ. Breakage of a thoracic epidural catheter during its removal -A case report- Korean J Anesthesiol. 2010;58:56972.http:// dx.doi.org/10.4097/ kjae.2010.58.6.569. [PMC free arti - cle] [PubMed]

11. Lenox WC, Kost-Byerly S, Shipley R, Yaster M. Pediatric caudal epidural catheter sequestration: an unusual complication. Anesthesiology. 1995;83:1112-4.

12. Nishio I, Sekiguchi M, Aoyama Y, Asano S, Ono A. Decreased tensile strength of an epidural catheter during its removal by grasping with a hemostat. Anesth Analg. 2001;93:210-2

13. Schummer W, Schummer C. Another cause of epidural catheter breakage? Anesth Analg.
2002;94:233.

http://

dx.doi.org/10.1213/00000539200201000-00047.

14. Mitra R, Fleischmann K. Management of the sheared epidural catheter: is surgical extraction really necessary? J Clin Anesth. 2007;19:310-4.

15. Pant D, Jain P, Kanthed P, Sood J. Epidural catheter breakage: A dilemma. Indian J Anaesth. 2007;51:434-7.

16. Lee YH, Hwang HY, Sim WS, Yang M, Lee CJ. Breakage of a thoracic epidural catheter during its removal - A case report. Korean J Anesthesiol. 2010;58:569-72.

17. Mitra R, Fleischmann K. Management of the sheared epidural catheter: Is surgical extraction really necessary? J Clin Anesth. 2007;19:310-4.

18. Coombs DW,Franklin JD,Meier FA,et al.Neuropathologic lesions and CSF morphine during chronic continuous intraspinal morphine infusion: a clinical \& post mortem study.Pain 1985;22:337-51.

19. Sidhu MS,Asrani RV,Bassell GM. An unusual complication of extradural catheterization in obstetric anaesthesia. Br J Anaesth 1983; 55:473-75

20. Pasquariello C,Betz R. A case for the removal of the retained intrathecal catheter. Anesth Analg 1991;72:562.

21. Ugboma $\mathrm{S}, \mathrm{Au}$ - Truong $\mathrm{X}$, Kranzler LI, et al. The breaking of an intrathecally placed epidural catheter during extraction. Anesth Analg 2002; 95: 1087 - 9.

22. Gough JD, Johnston KR, Harmer M. Kinking of epidural catheters. 
Anesthesia. 1989;40:1060

23. shikawa $\mathrm{Y}$, Magma $\mathrm{S}$, Ito $\mathrm{Z}$, et al. Delayed onset of subdural hematoma following epidural catheter breakage. Global spine J. 2016;6 (1):e1-6.

24. Vallejo MC, Adler LJ, Finegold H, Mandell GL, Ramanathan S. Periosteal entrapment of an epidural catheter in the intrathecal space. Anesth Analg.
2001;92:1532-4.

http://

dx.doi.org/10.1097/00000539200106000-00036. [PubMed]

25. Mitra, R, Fleischmann, K. Management of the sheared epidural catheter: is surgical extraction really necessary? Journal of Clinical Anesthesia 2007; 19: 3104. 